\title{
The relationship among ethics and conflict management in Hungarian metal and machinery supply chains
}

\author{
N. PIRICZ \\ Department of Management and Enterprise Sciences in University of Dunaújváros, piriczn@uniduna.hu
}

\begin{abstract}
It seems that ethics has become an important issue because more and more firms accept ethical codex and make them public as well. On contrary all of us know some stories when unethical behaviour resulted tragedy. Nowadays in business life ethics and responsibility appear as necessary value from the aspect of success. More papers state that ethical behaviour offers various benefits in business relationships. Our paper seeks these positives in empirical way by interviewing members and experts of Hungarian metal and machinery supply chains but we take into consideration the network effects as well. Our survey investigates how fair behaviour can prevent or decrease conflicts in business. The results of our qualitative research show that fair behaviour brings certain benefits but the economic reality and the direction of money flow are dominant. We have met various forms of conflict management and found that respondents want to maintain even very problematic business ties as well.
\end{abstract}

\section{Introduction}

When we look back in history we see that ethics has already appeared in the Old Testament in the form of the Ten Commandments (Deuteronomy 5:7-21) but in the New Testament Jesus makes these stricter and more concrete (Matthew 5:17-48) when for example he says:"You have heard that it was said to those of old, 'You shall not murder; and whoever murders will be liable to judgment.' But I say to you that everyone who is angry with his brother will be liable to judgment" (Matthew 5:21-22 English Standard Version). Beside his main mission (salvation of people which results entrance in heaven) Jesus calls attention to our motives therefore urges self-examination.

For centuries religious rules and norms played an important role in business e.g. in Europe and the USA but we can identify some signs in certain Arab countries as well. It seems that due to globalisation these views disappear or at least the roots of these norms become forgotten. In the 1970s courses on business ethics appeared in US schools (Hoffman et al. 2014) and the case of Enron in 2001, later the 2008 financial crisis make public, scholars and managers dawn on importance and actuality of business ethics.

However we still face astonishing cases. In Bangladesh in 2013 the 8-storey Rana Plaza (in Savar) collapsed due to textile factories on the top level. After the tragedy it turned out that the upper 4 stories were built without necessary permissions and basically the Plaza was planned for shops and offices and not factories using heavy, pulsating machines! In this tragedy 1129 people died and about 
2515 injured (Marriott 2013). Approximately 5000 employees created clothes here for world-famous companies such as Benetton or Wal-Mart. The official investigations and demonstrations raise not only the directly involved persons' - architects, factory leaders, owners - but also the multinational companies' responsibility who participate in the textile supply chains. This story calls attention to ethical behaviour and additionally proves the ethical responsibility of business networks as a whole as well.

Existence of supply chains is not a new invention at all while high-level satisfaction of consumer needs or close and long-term business relationships are well-known goals and methods in business sphere. The new tendency is the changes in business environment, which have strong effects and have resulted in creation of more and more supply chains (Gelei 2008).

According to more researchers (e.g. Hunger and Stern 1976) the contrary of conflict is cooperation. Why are there conflicts among business partners? Logical answer is permanent changings in the fields of politics, economies, regulations, social norms and technological systems. It can also happen that in a new business network a company has to cooperate with its former competitor (Hagberg-Andersson and Tidström 2008). Gadde and Håkansson (1993) claim cooperation conflict and even competition can exist among each other.

Therefore our study shows a short summary of relevant literature. In the second part of our study we introduce the first findings of our on-going survey when we ask with in-depth interviews Hungarian companies and advisors from metal and machinery industries about the roles of business ethics and conflicts in business.

\section{Literature review of business ethics and conflicts}

"There is an interaction between goals and means" (Håkansson, Harrison, and Waluszewski, 2007). In other words means do not necessarily follow goals; they may co-produce one another. A business relationship is usually developed through expectations of continuity which is fulfilled during repetitive transactions (Håkansson, Snehota 1995). Meanwhile trust and commitment towards the relationship deepen. The long term cooperation within a network requires adaptation where for example relationship-specific assets make this interactive dependency even more complex (Håkansson, Snehota 1995). The ethical behaviour as a result of processes and performances can increase the involved actors' wish to continue investments and improvements of competitiveness at network level (Praxmarer-Carus, Sucky, Durst 2013). On contrary unethical behaviour can weaken plans and future expectations (Hunt, Vitell 2006).

"Ethics refers to a system or code how we code of conduct based on moral duties and obligations which indicate how we should behave; it deals with the ability to distinguish right from wrong and the commitment to do what is right." (Hoffman et al. 2014:32) Business ethics is a form of applied ethics. "Business ethics is the study of what constitutes right and wrong, or good and bad, human conduct in a business context." (Shaw 2016:4) It includes not only the analysis of moral norms and moral values, but also attempts to apply conclusions of this analysis to that assortment of institutions, technologies, transactions, activities and pursuits that we call business (Velasquez, 2012). 
The ethical behaviour can be more vital in asymmetric business ties where ownership and use of resources are unbalanced (Mouzas, Ford 2007). We see that asymmetric business relationships belong to hot topics but its network aspect is less investigated. Mouzas and Ford (2007) state that interactive dependency does not definitely mean equal access to resources and it may happen that even the actors have chosen this case.

Halinen and Jokela (2014) introduce Valtra as good sample for ethical behaviour. The Finnish tractor manufacturer has built up with its 200 suppliers a well operating network in which Valtra plays a dominant role. But this role does not mean to misuse its network position or take exclusively its own advantages. Above all in Valtra's view ethical or fair behaviour does include introduction and fulfilment of clear economic and technical requirements towards the suppliers (Piricz 2015). Both concrete cases and publications suggest that ethical behaviour can offer various benefits (see Table 1).

\begin{tabular}{l}
\hline acting to prevent a substantial harm to others (Robin 2009) \\
\hline contributes to successful performance (Ferrell et al. 2012) \\
generally has positive effects on diadic relationships (Luo 2009) \\
\hline increase profit (Luo 2009) \\
\hline generally has positive effects on dyadic relationships (Halinen et al. 1999) \\
results more stabile business relationships (Luo 2006) \\
larger satisfaction between the partners (Brown et al. 2006) \\
less conflicts (Christopher - Gaudenzi 2009) \\
growing reputation (Christopher - Gaudenzi 2009) \\
\hline improves long term competitiveness and economic performance (Halinen - Jokela 2014)
\end{tabular}

Table 1: Summary of benefits of ethical behaviour among business partners

How we approach the relationship between CSR and ethics is the following: Kotler and Lee (2005) see CSR as commitment for the community level well-being of the firm; for these aims the firm voluntarily choose the relevant business practice and uses its resources accordingly as well. The European Commission's definition is: "Corporate social responsibility (CSR) refers to companies taking responsibility for their impact on society" (http://ec.europa.eu). Its most frequently used topics are sustainable supply chain, customer relationship, product security, environmental-friendly processes and technologies, decrease of waste and various types of pollutions, fair price tactics, ethical advertisements etc. (European Commission 2004). While the definition of CSR has developed during time Frederick (1978) identified 3 categories of CSR:

- CSR1: ethical - philosophical content of CSR,

- CSR2: action-oriented management concept of social sensitivity,

- CSR3: normative and rule-making element based on value and morality. 
As we see the notion of ethics appears in definitions of CSR so we can say ethics is an integrated vital part of CSR where CSR means not only nice visible campaigns but also really conscious strategy.

While our study investigates the Hungarian situation let's have a look at the Hungarian empirical findings. An early survey of 1300 leaders of totally 325 enterprises in 1996 showed quite mixed picture about ethical behaviour (Chikán 1997). The researchers of this survey had the opinion that handling ethics at firm level was at an early stage while about 10 per cents of respondents had their own ethical codex. Those firms showed more ethical behaviour which tried to achieve larger turnover in developed export markets. But according to data the ethical behaviour of Western companies operating in Hungary were not outstanding in those years.

Some years later Szegedi (2001) investigated the Hungarian enterprises' responsibility and saw they basically focused on their buyers and owners. But she added that ethical sensitivity would probably improve in the following years. Hajnalka Csáfor (2010) found that the most important motivation of continuity of corporate social responsibility (CSR) of the interviewed large Hungarian firms was 'to apply for their basic company values'. This result seems to confirm Szegedi's view for strengthening ethical issues. In Csáfor's survey (2010) other essential priorities were: 'acting as ethical company', 'contribution to sustainable development' and 'maintenance of good reputation' finally 'getting more customers and new markets'.

The investigated small- and medium sized enterprises (SMEs) represent a little bit different opinion. The SMEs think that 'getting more customers and new markets' is the most important and only after this aspect come "decrease of costs', 'maintenance of good reputation'. Finally they rank 'acting as ethical company' and 'contribution to sustainable development' (Csáfor 2010). The two very different priority lists - based on sizes of respondents - prove that for SMEs the short term profitability plays a much more important role.

András et al. (2013) also find that nowadays firms are aware of CSR but it is often the question of money. Rajcsányi-Molnár et al. (2013) introduce detailed the innovative and complex CSR program of GYSEV (Győr-Sopron-Ebenfurt Railways owned by the states of Austria and Hungary) which includes both external CSR - developing better traffic consciousness and higher traffic security - and internal CSR with the aim of support of aging staff.

We also have found a cultural speciality during review of relevant Hungarian literature. When authors deal with issues of ethics they often focus on unethical behaviour or more concretely corruption (e.g. Fazekas et al. 2013; Czibik et al. 2010 and 2011).

Scholars identify factors which are assumed to affect negatively business ties. These are opportunism, power asymmetries and structural bonds (Bahlmann - Schulze - Spiller, 2007). But conflict is less frequently added to this list. Conflict is so called expressed struggle between at least two interdependent parties who perceive incompatible goals, scarce rewards, and interference from the other party in achieving their goals (Hocker - Wilmot, 1985). In other words "conflict is a way of life in relationships that can be explicitly and implicitly expressed, but it is the way in which we handle or manage these conflicts that determines the quality of our relationships" (Tatum and Eberlin, 2006). 
Celuch, Bantham and Kasouf (2011) state that trust has an important role in understanding conflict resolution.

The organizational conflict literature has identified three common forms of conflict: relationship conflict or affective conflict, task or cognitive conflict and process conflict (Panteli - Sockalingam 2005). Hagberg-Andersson and Tidström (2008) state conflict in business life is usually short-term while other scholars rather focus on the management of conflicts because this basically determine the quality of a business relationship (Tatum - Eberlin 2006).

A conflict also can be equal to a process which includes naturally more stages (Thomas 1992) and can be distinguished more characteristic types as well such as 1) latent conflict, 2) perceived conflict, 3) felt conflict, 4) manifest conflict and 5) conflict aftermath(Pondy 1967). Pondy (1967) also stresses role of conflicts as important types of latent conflict. Latent conflict is naturally embedded in every relationship and it can be considered as a "silent" or invisible factor that either remains as such or is perceived by the actors. Trust can be also called as an invisible factor which is often difficult to punctually determine and it is easier to experience when it is missing.

According to Kemp and Ghauri (1999) trust means such norms which are the results of long-term relationship development and are able to decrease the possibilities of conflict. This view was proved by Hausman (2001) as well who finds less coercion and conflict in case of longer relationships. Morgan and Hunt (1994) posit that "it is trust that leads partner to perceive that future conflictual episodes will be functional” (1994:26).

The base of cooperation is trust and planning (Dwyer, Schurr and Oh, 1987). Waluszewski and Håkansson (2006) however state that in case of trust asymmetry can cause difficulties furthermore trust is just a small part of the whole gamut of feeling. Tahtinen and Halinen-Kaila (1997) suggest that termination of a business relationship can affect all actors directly connected (e.g. buyer-seller) as well as future actors in both companies and other companies that are related to them within the overall network. Thus, they highlight the multi stages that characterize the dissolution of relationships as comprising intrapersonal, intra-company, dyadic, and network stages. In summary, the focal company either negotiations with its partner in order to restore the relationship (voice strategy) or terminates the relationship (exist strategy).

How can practitioners solve conflicts? It can be a comfortable method to involve neutral person or mediator as the third side (Jameson 1999) or introduction of a well-based communication program (Magrath - Hardy 1989). Focusing on settlement of conflict we should deal with the question of power. Power has been defined as the ability to manage the perceptions of the other party (French and Raven, 1959), the ability of a firm to affect decision-making and/or behaviour (Wilkinson, 1996), and the ability to influence the decision-making and actions of the other party (Kähkönen and Lintukangas, 2011). Meanwhile Johanson and Mattsson (1992) state, that relationship between firms define their positions, and the firm's position depends on the nature of its direct and indirect relationships with the other firms. Additionally many business relationships, although asymmetric in power terms, last for decades with all members of the network, in spite of difficulties and conflicts, appearing to remain successful (Blois, 2008). 
As conflicts can be considered as inevitable in inter-competitor cooperation it is important for competitors to find ways of managing conflict as it occurs. (Hagberg-Andersson and Tidström, 2008) According to Kemp and Ghauri (1999) trust and norms, which is a result of long-term development, reduce the potential for conflict. More empirical surveys confirm such views that conflicts are not exceptions but rather normal in business life (e.g. Waluszewski and Håkansson 2006; Hocker - Wilmot, 1985; Tatum and Eberlin, 2006; Hausman 2001).Piricz et al. (2012) investigate first the relationship between trust and conflict then interaction between conflict and satisfaction (with business tie) and they find conflict seems to be a normal part of business life.

From an inter-organizational perspective Vaaland and Håkansson (2003) distinguish between formal and informal governance mechanisms. Formal conflict management mechanisms are related to compliance, awareness, comprehensive planning and structure. Informal conflict management mechanisms are related to trust, flexibility, lack of planning and process. Debrah et al. (2006) claim that business partners have minor problems those are obvious in their daily activities and business operations. The buyer is aware of the possibility of the problem happening in a real life situations. This is amicably solved by the two companies.

We use now Chikán's (2004) definitions for supply chain: such value creating row of processes, which is necessary for establishment of certain product and service package and steps out the boundary of cooperating organizations in order to satisfy customer demands. The building stones of supply chains are the different kinds of organizations and their relationships.

The conceptual framework of supply chain in Cooper et al's(1997) view emphasizes the interrelated nature of supply chain management (SCM) and the need to proceed through several steps to design and successfully manage a supply chain. Therefore they identify three groups which can describe supply chains: The supply chain network structure consists of the member firms and the links between these firms. Business processes are the activities that produce a specific output of value to the customer. Finally the management components are the managerial variables by which the business processes are integrated and managed across the supply chain (Cooper, Lambert and Pagh 1997).

If we look around we identify some special features of supply chain management in Hungary. New business networking seems to be quite slow process in Hungary. Kolos et al. (2006) investigated 301 companies in Hungary, which employ more than 50 persons and find that only 52 interviewed companies (17.6 percents) indicated strategic alliances. Besides strategic alliances the respondents prefer horizontal alliances and among activity fields marketing was the most frequent activity of horizontal cooperation. The majority of the interviewed firms have the opinion that strategic alliances have positive effect on their output and turnover furthermore 41 percents of the respondent plan to develop strategic cooperation within 3-5 years.

Hámori et al. (2007) investigated the competitive and cooperative behaviours of companies and find that 63 percents of respondents (50 persons) though that cooperative attitude is low among economic actors and in 22 cases (28 percents) identified lack of trust as result. The second frequent reason was lack of cooperation. It is a paradox situation that 20 percents of respondents think market economy as cause of low cooperation willingness. Kolos et al. (2006) also find that such characters of inter- 
personal relationships as sincerity, reliability and readiness to help, have basic importance in evaluation of relationships.

Therefore our research questions are:

- Do companies identify benefits of fair behaviour?

- Does fairness decrease or prevent conflicts?

- How can fairness influence their operating and business ties from the context of their supply chains?

\section{Applied methodology}

Our empirical survey is the Hungarian pillar of a Finnish research in University of Turku where the methodology was developed and tested. We used depth interviews of qualitative methodology (Malhotra, 2007) because of the very sensitive topic. For instance Welch et al. (2002) could use almost only qualitative methodology in the survey of relationship between politics and business.

So qualitative methodology usually gives chances to understand or stumble upon deeper, unexpected or even hidden correspondences. The respondent's choice and use of words or meta-communicative signs also belong to empirical data (Yeung 1995). During a qualitative Danish research a respondent consequently used 'challenge' instead of 'problem'. This clearly means that he sees problem as a challenge and a task to solve.

In case of depth interview it is well known that the person of interviewer is outstanding. These persons should be experienced enough to recognize and deal well the tiny signs as well. The trust between interviewer and respondent should develop already before conversation or latest at the beginning of talk (Malhotra, 2007). During depth interview interviewer encourages the other partner and tries to avoid such mistake of influencing the interview in any way because this could affect the final results especially. The depth interview shows a situation in that moment which origins from various historical, economic, social and technological processes and events (Ragin 2008).

In our study the depth interviews are semi-structured so there are quite detailed sub points and naturally it is not obligatory to answer each question. Our aim is to use out flexibility of this method (Yeung 1995) and to give freedom for respondents to speak bravely about such a sensitive topic. Certainly we guarantee anonymity during data collection, analysis and publications as well.

Due to the fact that qualitative methodology needs fewer respondents, the choice of respondents is more important. After collection of data, careful listening and re-listening and analysing of interviews require many working hours. Thematic analysis seems the most common form of analysis in qualitative research (Guest 2012) and we also have used thematic analysis after Miles and Huberman (1994).

We choose metal and machinery sectors because in Hungary the role of machinery - and within that car production - became very vital in the last decades. In the $2^{\text {nd }}$ quarter of 2014 Hungary had a nice GDP increase of 3.3 per cents (comparing with the $2^{\text {nd }}$ quarter of previous year). Gabler (2014), the market analyser of Erste Bank commented this as "the industrial production pulled the GDP increase, 
probably machinery and in it car production" Ürmössy, another market analyser of Erste Bank adds both in 2010 and 2011 the machinery sector gave a large part of industrial production. In 2010 car production represented 20 per cents of machinery sector but in 2014 this was almost 30 per cents (Panulin 2015). So a new investment of a multinational car company can make a measurable increase in the Hungarian GDP. That's why we think it is important to explore mechanisms and fair behaviour in these supply chains.

During pilot survey in Finland we saw that managers felt ethics too abstract and frequently asked if ethical business existed at all. Surprisingly this is also a question in Finland, in the least corrupted country of world. Based on these and other problems with the notion of ethics we have decided to use fair instead of ethical during data collection which may be a bit more concrete and less sensitive term for practitioners.

The smaller number of respondents certainly does not allow representative survey and general findings for the whole sector so this is the limit of our study. But we try to understand as many general issues and tendencies as possible that's why we ask not only representatives of companies but also experts of this field as well.

In this paper we deal with the Hungarian data. The seven depth interviews were made in 2015. We want to analyse various issues of fair behaviour in metal and machinery supply chains so our data are from two interviews with experts and four interviews with practitioners. These talks include various sizes of companies and their main distribution markets also different. A part of them sells their products only in domestic market but others produce dominantly for export markets. We plan to make additional depth interviews but for the time being we analyse below these conversations.

\section{The findings of our survey}

\section{How do you see the competition in your field?}

Some typical answers:

"This is not competition! It is impossible to compete with purely price-based evaluation. If a competitor makes an offer with irrationally law prices potential buyers expect us to follow this. Despite the firm which made this impossible offer went bankruptcy soon after this deal."

"The car assemblers ask more at lower prices. For instance at first the assembler orders 100 pieces for 1000 units but later 10000 pieces for 50 units."

"With almost all scope the category management decides which new suppliers can enter the network of the multinational company. There are some aspects of choice and about 200-page agreement what each supplier has to sign". (a large supplier directly to car producers, TIER-1 supplier)

The first opinion above indicates an unfair situation when a company should compete under unfair conditions. If a firm operates ethically, namely pays normal salary to employees and other costs, their base - from where they start their calculations - is higher so in a pure price-competition they are absolutely weaker. We get to know that the enterprise which gave this irrationally law prices had to terminate its activity after this deal but it seems there will other 'volunteers' for such an unfair role. 
In the other quotation above we see that car assemblers like to use out their role as large and important buyer. The car assemblers are aware of interactive connectedness with their suppliers but they feel they can afford these requirements as well. The third opinion similarly describes how supplier selection takes place. If we think however that a car involves thousands of spare parts coming from numerous suppliers which actually results huge managerial, administrative and financial tasks for the assembler. This requires effective organization which is able to manage thousands of suppliers, globally and regionally both strategic and operative level. So we may understand why car producers have developed very hierarchical structured and standardized methods for supplier selection, operation and conflict management as well. We also should consider when there is a serious problem with one spare part the whole set of concrete car has to be recalled which heavily ruins the brand name of the assembler and causes losses for suppliers indirectly. On the other hand when the 2008 crisis became general the first victims were from the car industry. While car is relatively expensive but contains thousands of spare parts customers postpone these purchases first. Sharply decreasing sales data immediately required suitable response, more concretely huge decrease in production and consequently much less orders from their suppliers. This seems that car supply chains - within manufacturing sector - is especially sensitive for changes and mistakes.

As an expert says the companies that exist nowadays in the Hungarian metal and machinery sectors were established by foreign capital. They have foreign ownerships still today. They pay taxes here and contribute to the Hungarian GDP but no other effects can come out of their company gates. He also thinks they do not turn back their profit into the Hungarian economy like a domestic enterprise. Regarding suppliers they seem to prefer foreign suppliers. This means if the firm has German major ownership they tend to favour German suppliers. So this interviewed expert asks what Hungarian is in metal and machinery sectors? Only the cheap labour force, he answers.

But we see some positive cases too. A respondent firm had the most dynamic development during crisis in 2008! Their motto was: there are crisis so we do not have time for waiting. They planned a logistic distribution centre in the next 3 years but finished within one year. The leadership of this German company says 'there won't be the winner who arrives the turning with the highest speed but who puts on the brake earlier'. Although German companies are excellent at wise cost decrease and optimization, in this case there were no sackings or resignation but decrease of salaries with compensation in other fields.

\section{What do you think about fairness?}

Some typical answers:

- (In the domestic market) "we work together with the largest firms and we do not have a voice in the contract."

- "The economic responsibility lasts for the point it does not conflict interests."

- "The aim is profit still today. The capitalist world operates like this. Only there are some bargains due to the interest of social cooperation."

- "I think there is headway but it was needed our edification and consciousness. This means if there is a suitable frame of contract system that is able to motivate both partners. Because in this not 
only one partner has obligations but also we have risks and maybe sacrifices. This system of conditions makes easy cooperative attitude." (TIER-1 supplier)

- "The fair behaviour almost always pays off. In quality management there is for example selfimprovement what both our buyers and we practice towards our suppliers. This is good because if the customer recognize a problem, comes here and it turns out that I have known that but did not mention, that is a much larger mistake."

- "We know there are certain partners who pay only if we ask payment before delivery."

- "When a customer was near to bankruptcy, instead of saying, I had difficulties so deliveries should be stopped, it announced quality complaints after deliveries. We travelled out, examined each pieces and the quality was right. This was quite uncomfortable."

- We meet very various cases and opinions regarding partners' fairness. Well this selection could also represent that the picture of fair behaviour is really colourful. We get to know such story when a respondent firm get across one of its business partners. Since that case they have asked 100 per cents pre-payment and even this relationship is still existing. Another respondent admits that they learn from the past and they usually start work when they have received a certain - not few - amount of advance payment. However they leave the last part of payment with the buyer and have respect for the buyer's interest if it want to utilize its quality requirements. The respondent thinks it is a right expectation of customer.

Each respondent explain an unethical story so it seems that this regularly appears in business. They try to learn from these cases but it is almost impossible to recognize these partners although very frequently there is the same scenario: In the first period they order several times and also pay normally. But in the second period they increase their order and either disappear without payment or state an artificial and not-right complain reasoning of non-payment. How could a firm avoid such partners or non-payment? Should they refuse when a buyer increase their order? of course not. Additionally a company leader states that he is not angry with his colleagues in such cases because everyone can meet this kind of partner.

\section{How would you describe communication and conflict management among your partners?}

Some typical answers:

- "We generally communicate through telephone, e-mail and personally too. But our documentary system is vital and we do not do anything without written confirmation. They sometimes ask to start work before signing contract but we do not begin." (leader of a medium-sized enterprise)

- "If the investment lasts for longer time we visit each other and we talk in a café or a restaurant. This is absolutely usual. This does not mean we fraternize each other." (leader of a medium-sized enterprise)

- "If we have conflict with a large-sized buyer, conflict management is one-sided; we apply and solve it."(leader of a medium-sized enterprise)

- "Each communication and conflict management is very formal and standardized. But trust relationships are necessary because they can speed up the processes. If there is trust, there is a small elbow-room." (TIER-1 supplier)

- "There are so called customer platforms. These show the latest reports what firms normally create about their suppliers. If a supplier achieves lesser points the buyer starts to vex that supplier because it is also the customers' interest that their suppliers achieve good performance." (a large supplier directly to car producers) 
- "Due to the more formal world, when the red button is flashing in the buyer's office, the buyer cannot do anything but start penalty because its ERP system determines that response. However I think besides automatism there should be place for human voice and argument too."(an expert)

- This latter expert adds that the tendency of automatism becomes stronger and in these daysmedium-sized firms also have an ERP (enterprise resource planning) system. On one hand this is good and modern but it hides inflexibility as well. Nowadays it is trendy to have and use some functions of any ERP but companies believe that this software will do everything instead of their staff. In practice however this makes operating so stiff, that logical relationships and solutions are excluded. This is a very important warning and this debate also raises an almost classical question regarding to negatives of technological development and high-level automatism. For example when there is amissing invoice-payment the ERP-protocol is immediately indicating so the administrator has to send the relevant warning to that buyer. If a buyer rather uses soft solution, concretely calls up partner and discusses what to do, payment might arrive a few days later but the relationship can become deeper and may include more possibilities for future businesses. Even in short term increased speed and automatism of processes and quick effective informal solutions can conflict with each other. Consequently the mentioned "human voice and argument" could offer such alternatives which can rescue cooperation in longer run.

It seems that formal way of conflict settlement can be identified mainly in large firms. More respondents explain that conflict settlement heavily depends on the partner's size. In case of large partner usually it is rather formal and may need more time, more departments. It seems that multinational companies insist to follow the relevant regulations of their handbook (including detailed hierarchical levels and the persons assigned, activities and deadlines etc.). (See Table 2 on summary of conflict management in our survey.)

On the other hand conflict management seems to be based on power. Generally this is equal to size but not always; if a medium-sized firm can offer special service or especially needed or unique spare-parts in smaller quantity. In certain cases smaller actors can be more competitive than multinationals and in this way it can represent larger negotiating power.

We find that in case of a large customer and SME as supplier, generally the smaller actor is required to behave one-sided much more flexible and more generously. It seems that these expectations are beyond the accepted struggle for buyer in general.

However in our investigation medium-sized respondents share more and innovative ways in conflicts. Despite conflicts and disputes they do not want to terminate any business ties but they tend to acts less open toward problematic buyer, for example they ask regularly pre-payment in large proportion of total amount. Other useful method is strong requirement of written confirmation. They do not start working earlier just for the sake of a buyer's phone call. But this practice is not general because another respondent states that in some cases they already start to work before signing contract. They have a long term trustworthy relationship with this buyer. So this means that SMEs are more open towards informal solutions and they can also behave in this way because their organizational structures and processes are usually simpler. These conditions give them better internal environment for person- or company tailored, prompt and effective conflict management.

Based on opinions we must see how closely communication and conflict management connect to each other. In other words proper - both flexible and effective - communication practice can offer better conflict management. This is really vital when we remember that well-known sociologic theory which 
says conflict belongs to normal life, including economics as well. This means that companies rather should focus on resolving their conflicts.

In Table 2 we show in what ways respondents try to prevent conflicts and handle at earlier stage. These tools are very various and starts with suitable atmosphere and includes understanding the other partners' interests and acting accordingly. This means that the supplier delivers the last valuable lot with deferred payment so as to give chance for buyer's quality compliment. The role of written confirmation may differ in respondents' views but we see that written communication can prevent misunderstanding and therefore it can be an effective tool in early conflict management.

Another form of written communication is the contract which also plays different roles based on depth interviews. Generally we state in certain situations a good contract is able to prevent majority of conflicts by establishing clear, mutually understood conditions and situations.

\begin{tabular}{|c|c|}
\hline \multirow[t]{3}{*}{ Formal } & according to enterprise resource planning system \\
\hline & according the scenarios of (multinational) buyer's handbook \\
\hline & self-accusation (often in quality management) \\
\hline \multirow[t]{3}{*}{ Informal } & discussion between coequal parties \\
\hline & smaller-sized partner behave more flexible \\
\hline & $\begin{array}{l}\text { ask other factories within same multinational about their experiences } \\
\text { regarding specific supplier }\end{array}$ \\
\hline \multirow[t]{5}{*}{ Prevention } & good and open mutual attitude \\
\hline & acception of the other party's interests \\
\hline & key informations only in written forms \\
\hline & good contract - good conditions \\
\hline & continuous partly or total pre-payment \\
\hline \multirow{2}{*}{$\begin{array}{l}\text { Termination } \\
\text { of } \\
\text { relationship }\end{array}$} & if a smaller-sized partner had payment difficulties, they replaced it \\
\hline & $\begin{array}{l}\text { if one partner would go to law this business tie would stop } \\
\text { immediately }\end{array}$ \\
\hline
\end{tabular}

Table 2: Ways and methods of conflict management in our survey

\section{How would you describe your supply chain and network practices?}

Some typical answers:

- "We are medium-sized not only from statistical aspects but also due to our position in our supply chain. We are stressed from above and below and also sideways."

- "According to our position in the food chain we already have to finance our activity but the firms below us are unable to finance themselves." 
- "Who is the dominant actor of supply chain? Just look at the direction of capital flow and you will immediately know it."

- "There is no freedom for anyone. The network affect is the system of conditions where I live in."

- "The impacts of multinationals are strong. They misuse their power including unwritten rules too."

- "I remember a case when a project was postponed one year because one subcontractor did not indicate serious problems and did not strive to cooperate."

As a summary we state that respondents are usually aware of various network affects. It seems that this is already a natural part of their environment. However we find another common feature of supply chains; this is the dominant role of the largest member of supply chain. This actor is generally located closest to the final customer. For example during procurement a large company receives the complex order and it gives many orders and tasks further to its subcontractors and these subcontractors also give further to their subcontractors etc. In other case the car assembler has almost direct contact with buyer - through different levels of traders - and this position gives them both responsibility (as it was explained earlier) and power. It seems they practically instruct their suppliers and they are not really interested in their suppliers. Certainly it is also the assembler's interest that suppliers fulfil good performance but the car assemblers treat them severely.

\section{Conclusions}

Investigation of supply chains belong to B2B contexts where there are lesser actors that's why these actors are more valuable and it is more complicated to replace them. Even when respondents meet unfair behaviour they do their best to maintain those business ties as well but at the same time try to avoid legal procedures. It seems the small and medium-sized firms accept power and dominancy of large firms and try to handle this situation as an objective factor of their life.

As we see the interviews represent quite various picture concerning ethics and some connecting issues. It is surprising and interesting when we inquire about competition, in most cases they start to speak about fairness. The opinions on general development of fairness is varying because some respondents explain negative tendencies and growing numbers of unfair stories while some others identify positive changes in this field. Especially a respondent from quality insurance is optimistic and sees improvements. However a company owner simply says that he feels himself well when he behaves fairly. This means that both market forces, economic logic and internal need can result ethical behaviour. Both experts and the majority of managers agree that very unethical behaviour finally will have relevant consequences. But on contrary the very ethical companies will not reap their reward. It seems a little bit strange and does it give lesson to find the 'optimal' way some when between?

It seems that size and position in the supply chain are the two most important factors which influence behaviour of companies in metal and manufacturing sectors. The leaders' and owners' personal attitude play another vital role.

Logically communication and conflict management have close relationship with each other. If communication is continuous, open and involves different levels, forms and channels, this gives a natural base to identify, share and settle disputes at an early stage. That's why regulated, very structured and limited 
communication offered by any enterprise resource planning system may exclude quick, effective but informal conflict settlement.

We meet several tools and practices both for prevention and management of conflicts in business. We also confirm the view of Vaaland and Håkansson (2003) regarding formal and informal governance mechanisms. It seems that larger firms prefer formal, standardized solutions while SMEs are more open towards flexible and personalized conflict settlement. This does not mean that business ties would not be important for large companies. They also desire to maintain all of their relationships independently if it is problematic or not. They also seek solutions but usually in a more hierarchical and structured way. This does not include sometimes to ask the other daughter factories about a certain business partner and to use this information accordingly.

We confirm that conflict is natural part of business and actors try to use many kinds of methods because contracts and orders from buyers can guarantee successful operation. The question seemingly is still open if we approach to more ethical business or not.

\section{References}

[1] I. András, M. Rajcsányi-Molnár, G. Füredi (2013), A vállalatilag felelös vállalat - A CSR és a cafeteria-metszetértelmezési lehetôségei a gyakorlatban, In Metamorfózis - Glokális dilemma három tételben (Szerk.: AndrásIstván - Rajcsányi-Molnár Mónika) Új Mandátum Könyvkiadó, 2013, pp 127-139

[2] J. Bahlmann, B. Schulze, A. Spiller (2007), Trust as a supply chain management tool for slaughterhouses: Empirical evidence from north-western Germany, Paper presented at the 17th Annual World Forum and Symposium "Agribusiness Food Culture: Tradition, Innovation and Trust - A Positive Force for Modern Agribusiness", IAMA Conference, June, 2007 in Parma, Italy

[3] K. Blois (2008), The Legitimation of Power in Business to Business Relationships, Proceedings of the 24th IMP Conference, Uppsala, Sweden

[4] J. R. Brown, A. T. Cobb, R. F. Lusch (2006), The roles played by inter-organizational contracts and justice in marketing channel relationships, Journal of Business Research, Vol. 59, No. 2, 166-175.

[5] K. Celuch, J. H. Bantham, C. J. Kasouf (2011), The role of trust in buyer-seller conflict management, Journal of Business Research, Vol. 64, Issue 10, October, 1082-1088

[6] A. Chikán (1997), Vállalatok és funkciók integrálója - Folyamatjellegú irányítás - alprojekt zárótanulmánya, Budapesti Közgazdaságtudományi Egyetem, Vállalatgazdaságtan Tanszék

[7] A. Chikán (2004), Vállalatgazdaságtan, Aula Kiadó, Budapest

[8] M. Christopher, B. Gaudenzi (2009), Exploiting knowledge across networks through reputation management, Industrial Marketing Management, Vol. 38, No. 2, 191-197. 
[9] M. C. Cooper, D. M. Lambert, J. D. Pagh (1997), SupplyChain Management: More Than a New Name for Logistics, The International Journal of Logistics Management, 8(1), 1-13

[10] Á. Czibik, M. Hajdu, Á. Makó, I. J. Tóth, Z. Várhalmi (2011), Integritás és korrupciós kockázatok a Magyar vállalati szektorban, MKIK Gazdaság- és Vállalkozáskutató Intézet, Budapest

[11] H. Csáfor (2010), Mennyire felelősek az Észak-magyarországi region vállalatai?, Periodica Oeconomica, III. ÉVF. November (22-36. o.)

[12] I. K. Debrah, N. Bashir, R. Thongkum (2006), Factors affecting trust and commitment in Business to Business Relationship (B2B), A case study of astmaland Lan Tidning(VLT),Vastmaland Tidning (V.TAB), Morten Maskin and Bombardier Transport, Västerås - Sweden. SCHOOL OF BUSINESS Västerås Mälardalen University, Master Thesis

[13] J. Dyer, W. Chu (2003), The role of trustworthiness in reducing transaction costs and improving performance: Empirical evidence from the United States, Japan, and Korea, Organization Science, 14(1), 57-68.

[14] European Commission (2004), ABC of the main instruments of Corporate Social Responsibility, European Commission, Directorate-general for Employment and Social Affairs, Brussels

[15] European Commission http://ec.europa.eu/growth/industry/corporate-socialresponsibility/index_en.htm 12.10.2015

[16] M. Fazekas, I. J. Tóth, P. K. Lawrence (2013), Anatomy of grand corruption: A composite corruption risk index based on objective data, Corruption Research Centre Budapest

[17] O. Ferrell, J. Frederich, L. Ferrell (2012), Business ethics: Ethical decision making \& cases, (Vol. 9). Boston: Cengage Learning

[18] C. Frederick, William (1994), From CSR1 to CSR2, Working paper 249, Graduate School of Business, University of Pittsburgh, 1978. Its 2nd edition: Business and Society, Vol 33, no. 2, August, 150-164

[19] J. R. P. French, B. Raven (1959), The bases of social power, in Studies in social power, A. Arbor, ed., University of Michigan Press, Dorwin Cartwright

[20] G. Gabler (2014), Húzza az autóipar a magyar GDP-t, http://www.autoszektor.hu/hu/content/huzza-az-autoipar-magyar-gdp-t (20.05.2015)

[21] L.-E. Gadde, H. Håkansson (1993), Professional Purchasing, Routledge, London

[22] A. Gelei (2008), Hálózat - a globális gazdaság kvázi szervezete, Budapesti Corvinus Egyetem, 95. sz. Műhelytanulmány HU ISSN 1786-3031

[23] G. Guest (2012), Applied thematic analysis, Thousand Oaks, California: Sage

[24] A. Hagberg-Andersson, A. Tidström (2008), Conflict management in intercompetitor cooperation, The 25th IMP Conference proceedings, Uppsala, Sweden 
[25] H. Håkansson, I. Snehota (ed.) (1995), Developing relationships in business networks, London, Routledge

[26] H. Håkansson, D. Harrison, A. Waluszewski (2007), Introduction: Rethinking marketing, In Håkansson Harrison \&Waluszewski (Eds.), Rethinking marketing London: JohnWiley and Sons

[27] A. Halinen, A. Salmi, V. Havila (1999), From dyadic change to changing business networks: An analytical framework", Journal of Management Studies, Vol. 36, No. 6, 779-794.

[28] A. Halinen, J. Päivi (2014), Exploring Ethics in Business Networks: Propositions for Future Research, IMP Conference Bordeaux, France

[29] B. Hámori, K. Szabó, A. Derecskei, H. Hurta, L. Tóth (2007), Versengő és kooperatív magatartás az átalakuló gazdaságban, Közgazdasági Szemle (Journal of EconomicLiterature), LIV. évf. June, 579-601.

[30] A. Hausman (2001), Variations in Relationship Strength and Its Impact on Performance and Satisfaction in Business Relationships, Journal of Business and Industrial Marketing, 1 (6/7), 600-616.

[31] J. L. Hocker, W. W. Wilmot (1985), Interpersonal Conflict, Second edition, William C. Brown, Dubuque, IA.

[32] W. M. Hoffman, R. E. Frederick, R. E. Schwartz (2014), Business Ethics, Reading and Cases in Corporate Morality. 5th edition, Pearson

[33] J. Hunger, L. Stern (1976), An assessment of the functionality of the superordinate goal in reducing conflict, Academy of Management Journal, Vol. 19, pp. 591-605

[34] S. Hunt, S. Vitell (2006), The General Theory of Marketing Ethics: A Revision and Three Questions", Journal of Macromarketing, Vol. 26, No. 2, 143-153.

[35] J. Jameson (1999), Toward a comprehensive model for the assessment and management ofintraorganizational conflict: Developing the framework, The International Journal ofConflict Management, Vol 10 No 3, pp. 268-294

[36] J. Johanson, L. G. Mattsson (1992), Network positions and strategic action - An analytical framework, in Industrial networks: A new view of reality, B. Axelsson and G. Easton, eds., Routledge, London, p. 205-217.

[37] R. Kemp, P. N. Ghauri (1999), Cooperation and conflict in international joint venture relationship, Proceedings of the 15th Annual IMP Conference, Dublin

[38] K. Kolos (ed.) (2006), Vállalatközi kapcsolatok és a versenyképesség összefüggései Projektzáró-tanulmány, BUDAPESTI CORVINUS EGYETEM - VÁLLALATGAZDASÁGTAN INTÉZET, 44. sz. Múhelytanulmány

[39] Y. Luo (2006), Toward the micro- and macro-level consequences of interactional justice in cross-cultural joint ventures, Human Relations, Vol. 8, No. 59, 1019-1047. 
[40] Y. Luo (2009), From gain-sharing to gain-generation: The quest for distributive justice in international joint ventures, Journal of International Management, Vol. 15, 343-356.

[41] A. K. Kähkönen, K. Lintukangas (2011), Does power matter? The role of power in supplier relationship management, Proceedings of the 27th Annual IMP Conference, Glasgow, Scotland

[42] P. Kotler, N. Lee (2005), Corporate Social Responsibility: Doing the Most Good for Your Company and Cause, Hoboken, New Yersey: John Wiley \& Sons, Inc., 2005.

[43] A. Magrath, K. Hardy (1989), A Strategic Paradigm for Predicting Manufacturer-Reseller conflict, European Journal of Marketing, Vol 23 No. 2, 94-108.

[44] K. Malhotra, Naresh (2007), Marketing research, Pearson

[45] R. Marriott (2013), The house of cards: the Savar building collapse, libcom.org (05.02.2015)

[46] M. B. Miles, A. M. Huberman (1994), Qualitative Data Analysis: An Expanded Sourcebook, 2nd Edition, Thousand Oaks, California, USA: Sage Publications Inc., 1994.

[47] R. M. Morgan, S. D. Hunt (1994), The Commitment - Trust Theory of Relationship Marketing, Journal of Marketing, 58: 20 - 38.

[48] S. Mouzas, D. Ford (2007), Contracts in asymmetric relationships, The Proceedings of the 22nd IMP Conference, Milan

[49] I. Panulin (2015), Egy új autógyártó megjelenése így hatna a magyar GDP-re, 2015.02.13.http://inforadio.hu/hir/gazdasag/hir-700595 (20.05.2015)

[50] N. Panteli, S. Sockalingam (2005), Trust and conflict within virtual inter-organizational alliances: a framework for facilitating knowledge sharing, Decision Support Systems 39, pp. $599-617$

[51] S. Praxmarer-Carus, E. Sucky, S. M. Durst (2013), The relationship between the perceived shares of costs and earnings in supplier development programs and supplier satisfaction, Industrial Marketing Management, Vol. 42, No. 2, 202-210.

[52] N. Piricz, T. Mandják (2012), The relationship among trust conflicts and perceived satisfaction in B2B context, Proceedings of the 28th Annual IMP Conference, Rome

[53] N. Piricz (2015), Fair magatartás az üzleti hálózatokban, EMOK Konferencia Budapest Műszaki és Gazdaságtudományi Egyetem

[54] L. Pondy (1967), Organizational Conflict: Concepts and Models, Administrative Science Quarterly, Vol. 12, pp. 296-320

[55] C. C. Ragin (2008), Redesigning Social Inquiry: Fuzzy Sets and Beyond, University of Chicago Press, Chicago

[56] M. Rajcsányi-Molnár, I. András (2013), Önkéntes társadalmi felelősségvállalás - Innovációs CSR - rendszerépítés egy magyarországi nagyvállalatnál, In: Metamorfózis - Glokális 
dilemma három tételben (Szerk.: András István - Rajcsányi-Molnár Mónika) Új Mandátum Könyvkiadó, pp 74-96.

[57] D. Robin (2009), Towards an applied meaning for ethics in business, Journal of Business Ethics, 2009, Vol. 89, No. 1, 139-150

[58] W. H. Shaw (2016), Business Ethics, 9th edition, Cengage Learning

[59] K. Szegedi (2001), A Magyar vállalatok etikai érzékenysége, Ph.D. értekezés. Miskolci Egyetem

[60] B. C. Tatum, R. J. Eberlin (2006), Organizational justice and conflict management styles, International Journal of Conflict Management, Vol. 17 No 1, pp. 66-81.

[61] J. Tahtinen, A. Halinen-Kaila (1997), The death of business triads: dissolution process of a net of companies, in: Mazet, F., Salle, R. \& Valla, J. (Eds), Interaction, Relationships and Networks, Proceedings of the 13th IMP International Conference, Lyon, pp. 553-90.

[62] K. W. Thomas (1992), Conflict and conflict management, in Dunnette, M.D. (ed.) Handbook of Industrial and Organizational Psychology, Chicago, IL, Rand McNally

[63] A. Tidström (2008), Perspectives on Coopetition on Actor and Operational Levels, Management Research: Journal of the Iberoamerican Academy of Management, Vol. 6 Iss: 3, pp.207 - 217

[64] T. Vaaland, H. Håkansson (2003), Exploring interorganizational conflict in complex projects, Industrial Marketing Management, Vol. 32 No 2, pp. 127-138.

[65] M. G. Velasquez (2012), Business Ethics - Concepts \& Cases, Pearson Education, Inc.

[66] A. Waluszewski, H. Håkansson (2006), The importance of angry actors, Proceedings of the 22nd Annual IMP Conference, Milan, Italy

[67] C. Welch, R. Marschan-Piekkari, P. Heli, T. Marja (2002), Corporate elites as informants in qualitative international business research, International Business Review 11, 611-628

[68] I. F. Wilkinson (1996), Distribution channel management: Power considerations, International Journal of Physical Distribution \& Logistics Management, 26 (5), 31-41.

[69] H. Yeung, Wai-chung (1995), Qualitative Personal Interviews in International Business Research: Some Lessons from a Study of Hong Kong Transnational Corporations, International Business Review, Vol. 4, No. 3, pp. 313-339 